\title{
Personality and temperament of Olympic taekwondo competitors and their level of advancement and sports performance
}

Authors' Contribution: A Study Design B Data Collection C Statistical Analysis D Data Interpretation E Manuscript Preparation

F Literature Search G Funds Collection

\author{
Marta Remiszewska ${ }^{1}$ BDF, Jerzy F. Miller ${ }^{1}$ ACDG, Marek Graczyk ${ }^{2}$ ABG, \\ Milena Lachowicz ${ }^{2}$ ADE \\ ${ }^{1}$ Faculty of Health Science, the State University of Applied Sciences, Lomza, Poland \\ ${ }^{2}$ Department of Social Sciences, \\ Gdansk University of Physical Education and Sport, Gdansk Poland
}

\section{abstract}

Background:

Material and methods:

Results: Having analysed the data, it turned out that the two researched groups (juniors and seniors) were similar regarding a low level of anxiety and neuroticism, a high level of extroversion and an average level of agreeableness. The only variable significantly differentiating competitors in junior and senior groups was neuroticism.

Conclusions: In the junior group, it was extroversion that differentiated the competitors with or without medals, in the senior one - agreeableness.

Key words: Olympic taekwondo, personality, temperament, sport performance.

\section{article details}

Article statistics:

Full-text PDF:

Received: February 2020; Accepted: April 2020; Published: June 2020

http://www.balticsportscience.com

Indexation: Celdes, Clarivate Analytics Emerging Sources Citation Index (ESCI), CNKI Scholar (China National Knowledge Infrastructure), CNPIEC, De Gruyter - IBR (International Bibliography of Reviews of Scholarly Literature in the Humanities and Social Sciences), De Gruyter - IBZ (International Bibliography of Periodical Literature in the Humanities and Social Sciences), DOAJ, EBSCO - Central \& Eastern European Academic Source, EBSCO - SPORTDiscus, EBSCO Discovery Service, Google Scholar, Index Copernicus, J-Gate, Naviga (Softweco, Primo Central (ExLibris), ProQuest - Family Health, ProQuest - Health \& Medical Complete, ProQuest - Illustrata: Health Sciences, ProQuest - Nursing \& Allied Health Source, Summon (Serials Solutions/ProQuest, TDOne (TDNet), Ulrich's Periodicals Directory/ulrichsweb, WorldCat (OCLC)

Funding: This research received no specific grant from any funding agency in the public, commercial, or not-for-profit sectors.

Conflict of interests: Authors have declared that no competing interest exists

Dr Milena Lachowicz, Gdansk University of Physical Education and Sport; K. Górskiego 1 Str., Gdańsk 80-336, Poland; e-mail: millkawings@gmail.com

Open Access License: This is an open access article distributed under the terms of the Creative Commons Attribution-Non-commercial 4.0 International (http://creativecommons.org/licenses/by-nc/4.0/), which permits use, distribution, and reproduction in any medium, provided the original work is properly cited, the use is non-commercial and is otherwise in compliance with the license. 


\section{INTRODUCTION}

The prominence of psychological traits as well as mental preparation has long been known and regarded as one of the most significant elements of a player's holistic preparation. Coaches and competitors almost unanimously formulate an opinion that "sport of the highest level is $90 \%$ mind" [1]. Thus in search of the determinants of sport performance, it is difficult to omit psychological factors - athletes' psychological skills have an important role in the achievement of martial art sports [2]. Martial arts competitors are at risk of a high mental strain which is naturally different and dependent on individual level of training, personality traits, age, and the rank of the sports competition. The element that distinguishes martial arts from other types of sports is a direct physical contact with an opponent and an attempt to subdue them. The mental determinants of sports performance differentiating martial arts competitors from team sports competitors were the main subject of the study by Bernatek et al. [3]. The analysis of the results of their study shows that martial arts competitors (judo, boxing, karate), both in the junior and the senior groups, are more extrovert and emotionally stable compared to team sports competitors. It should be noted that team games athletes (close contact sports) present a higher level of extraversion comparing to individuals [4, 5].

The coaches and scientists name a low level of neuroticism and anxiety, and a high level of extroversion and motivation to be the most desirable mental traits of martial arts competitors and different sports [6-12]. Rychta [15] has also included the following determinants: the pursuit of a goal, resistance to stress connected with a fight, determination, and a low level of aggression. They have also stressed that the sport performance determinants change together with the ontogenetic development and an achieved sport result.

The studies of mental traits regarding high sports performance in taekwondo are rare; that is why the initial review of the studies began with an analysis of this variable in other combat sports, i.e. judo, boxing, wrestling, or karate. Obminski et al. [13] conducted a psychological profiling of boxing competitors in the junior group with and without successes. Using standardised questionnaires it was possible to determine the dominant personality traits, such as intelligence, the level of anxiety, neuroticism, extroversion, aggression, negation, suspiciousness, anger, irritability, and guilt. The results of the study showed that there were no significant differences in either of the researched traits in both groups.

Terelak and Gorska [14] conducted their research in a junior group doing judo dividing them into two teams: those reaching best results in sports, and those with relatively mediocre accomplishments. Sportsmen with the best results had a lower level of neuroticism and a higher level of extroversion than athletes not reaching similar results.

On the other hand, Botwina [9] examined the psychological characteristics of wrestling competitors. The factors characterising juniors were low neuroticism, contemplativeness, impulsiveness and the level of general aggression. In turn, seniors were characterised by high extroversion, the level of general aggression, and an average contemplativeness. In the group of the national team, low neuroticism, very high activity, very low contemplativeness and an average level of general aggression dominated. 
Wielochowski et al. [6] examined the national team's wrestling competitors (both styles) as well as judo in the junior and the senior groups. The study involved the measurement of anxiety, temperament and personality. It was concluded that the competitors of freestyle and classical wrestling as well as judo were characterised by a low level of anxiety, an optimal level of aggression, and the mobility of the nervous system.

Looking for individual differences in the field of psychological variables, in relation to their sports results in martial arts, i.e. judo, wrestling or boxing, temperament, personality, anxiety, motivation and thinking were studied. It was concluded that they primarily depended on sports discipline, but also on situational factors. However, high motivation was recognised as the most significant one. Corresponding with this view are the results of Rychta's studies which showed that there was a strong correlation between competitors' intentional behaviour and their personality traits, temperament, and motivation $[8,15]$.

The few results of research on psychological factors in relation to the sporting results of taekwondo competitors correspond with the above presented effects of this type of analysis in other martial arts. Ghorbanzadeh et al. [16] named anxiety, motivation and temperament to be significant factors influencing sport performance in taekwondo. On the basis of the research on the medallists of the Polish Taekwondo Championship, it was found that the factors that determine sports performance of the seniors are low neuroticism, high conscientiousness and extroversion, as well as a mixed temperament - a choleric with a sanguine. On the other hand, Kazemi et al. [17] and Saporta [18] named, among other significant factors characterising the Olympic taekwondo medallists, anxiety, motivation and cognition.

The presented results of research on psychological variables of martial arts competitors, with particular emphasis on taekwondo, indicate that further research is necessary to identify psychological factors in relation to sports results in taekwondo.

\section{MATERIAL AND METHODS}

Out of 20 randomly chosen sports clubs from 8 voivodeships, 127 Olympic taekwondo competitors were included in the study. All of them participated in the competition system for children and teenagers organised by the Polish Olympic Taekwondo Association (PZ TKDO - Polski Związek Taekwondo Olimpijskiego) and had valid licences and medical examinations.

The junior group ( $\mathrm{n}=63$, age range 15.2-17.4 years old) was divided into two subgroups according to their success in the Championships of Poland: winners ( $n=27$, places 1-3) and non-winners $(n=36$, places 5-16). The proficiency levels of the junior TKD athletes ranged from 6 kup to 1 dan and their competitive TKD experience was $7.4 \pm 2.82$ years.

The senior group ( $\mathrm{n}=64$, age range 18.3-22.1 years old) was also divided into two subgroups according to their success in the Championships of Poland: winners $(n=28$, places $1-3)$ and non-winners $(n=36$, places $5-16)$. Their proficiency levels ranged from 4 kup to 3 dan and their competitive TKD experience was $9.7 \pm 3.24$ years (Table 1 ). 
Table 1. Characteristics of the study sample

\begin{tabular}{lcc}
\hline Group & $\begin{array}{c}\text { Age (years) } \\
\text { Mean } \pm \text { SD }\end{array}$ & $\begin{array}{c}\text { Training experience (years) } \\
\text { Mean } \pm \text { SD }\end{array}$ \\
\hline Senior (total) & $19.7 \pm 2.48$ & $7.5 \pm 3.28$ \\
With medal & $19.7 \pm 2.41$ & $8.3 \pm 2.75$ \\
Without medal & $19.7 \pm 2.61$ & $6.6 \pm 3.60$ \\
Junior (total) & $15.9 \pm 0.84$ & $5.1 \pm 1.52$ \\
With medal & $15.7 \pm 0.85$ & $5.5 \pm 1.94$ \\
Without medal & $16.1 \pm 0.83$ & $4.8 \pm 1.26$ \\
\hline
\end{tabular}

The tested Olympic taekwondo competitors (juniors, seniors) participated in the organised training program run by their home clubs. Juniors trained 5 times a week for 90 minutes per class, whereas seniors trained 7 times a week for 120 minutes. The research was conducted in the second half of 2010 during the training season by a team of specialists under the direction of a psychologist.

The survey of mental traits included the measurement of anxiety, temperament, and personality.

Anxiety was examined by means of a questionnaire - State-Trait Anxiety Inventory - STAI - by C.D. Spielberger, R.L. Gorsuch, R.E. Lushene. The questionnaire consisted of two scales - X1, which tested anxiety as the state defined here and now, and X2, which tested anxiety as a trait marked by general fear. Each subject answered 40 questions marking the answers on a 4-level scale [19].

Temperament was examined by means of a questionnaire - Formal Characteristics of Behaviour-Temperament Questionnaire (FCZ-KT). It measures six temperament traits according to Strelau Temperament Inventory: briskness - a tendency to quick reaction, perseveration - a tendency to repeat and continue behaviour, sensory sensitivity - an ability to react to weak stimuli, emotional reactivity - a tendency to an intense reaction to stimuli, endurance - an ability to react adequately in situations requiring long-term activity or under conditions of high stimulation, activity - a tendency to behaviour of high stimulating value. The test consisted of 120 questions. The tested person gave Yes or No answers. The test is used in the study of teenagers and adults [20].

Personality was tested by means of Factor Inventory NEO-FFI by Costa and McCrae [21], characterising the personality structure in accordance with the Five-Factor Model. The items of the questionnaire are 60 self-report claims, whose truthfulness in relation to their own person, the subject evaluates on a five-point scale. The items are formed with five bipolar factors: neuroticism - reflecting emotional adaptability versus emotional disturbance associated with a tendency to experience negative emotions as well as vulnerability to stress, extroversion - describing the quality and quantity of social interaction, a tendency to have positive mood, and the focus of life energy, openness to experience - characterising a tendency of an individual to search and value positively their life experiences, a high cognitive curiosity and tolerance for new information, agreeableness - describing a positive or negative attitude towards another, determined by behaviour set for cooperation and providing help or competition and a higher tendency to aggressive behaviour, conscientiousness - reflecting the degree of commitment and motivation to activity oriented towards aim, strong will and perseverance of an individual. 
A review of data analysis was carried out by calculating basic characteristics, i.e. mean value, standard deviation, volatility indicators and Pearson correlation coefficient or Spearman rank correlation $[22,23]$. The next step in the analysis was a review of the correspondence of the distribution of individual variables with the normal distribution. For this purpose, the Shapiro-Wilk Test was employed. Depending on the confirmation or refutation of the hypothesis on the correspondence of the variable distribution with the normal distribution an analysis of variance was used to assess the difference between the groups - oneway ANOVA (in the first case) or the Kruskal-Wallis test (in the second case).

In order to establish the model describing the correlation between the dependent variable (the number of ranking points) and the number of independent variables a count data regression was used - Poisson model. This type of analysis was chosen for two reasons. The first - of a theoretical nature - the properties of Poisson's distribution were taken into account, which is the distribution of rare events, and describes, among others, the number of successes within a predetermined period of time, which accurately reflects the nature of the variable, which in this case is the number of ranking points accumulated in the number of competitions. Another characteristic of Poisson distribution is the equality of expected value and variance, so it was checked whether this condition was met. It was found that the average value of ranking points was approximately equal to the variance. This practical test was another reason for choosing the model described above. However, such an approach is met with certain limitations, which are mostly concerned with measurement errors connected to refereeing, the classification system, etc. Therefore, in the data analysis a tool was used, to determine, on the one hand, the influence of independent variables on the chance of scoring a point, and on the other, to determine those variables that are not conducive to achieving any sports effects (they contribute to the lack of any achievements, i.e. lack of points). As a criterion for the quality of a model AIC (estimator of quality of models) was adopted. Such an approach allowed the use of the regression method with a large number of zero values. In the statistical conducted analyses, $\mathrm{p}<0.05$ values were assumed to be significant.

\section{RESULTS}

Firstly, selected mental traits of Olympic taekwondo competitors in the junior and the senior groups were compared. The following personality traits were analysed: neuroticism, extroversion, openness, agreeableness, anxiety, and temperament. It was found that anxiety and temperament did not significantly differentiate between juniors and seniors, and so these factors were excluded from the subsequent analysis $(\mathrm{p}>0.05)$.

Only one psychological variable that significantly differentiated between the groups was noted. It was neuroticism. The seniors noted a lower level of this trait by $24 \%$ $(\mathrm{p}<0.001)$. In the remaining mental traits, juniors and seniors obtained similar values. The differences in the obtained values ranged from $1 \%$ to $4 \%$ (see Table 2 ).

The next stage was to compare the psychological factors of taekwondo competitors with various sport achievements (medal, no medal) in the junior and the senior groups. In the assessment of mental state differentiating the study groups, the following factors were taken into consideration: anxiety (state and trait), temperament (features - briskness, perseveration, sensory sensitivity, emotional reactivity, endurance, activity), personality (features - neuroticism, extroversion, openness to new experiences, agreeableness, conscientiousness). The results are presented in Tables 3 and 4. 
Table 2. The differences in the selected mental traits in Olympic taekwondo competitors in junior and senior

\begin{tabular}{lccccc}
\hline \multirow{2}{*}{ Trait } & \multicolumn{2}{c}{$\begin{array}{c}\text { Junior(J) } \\
(\mathrm{n}=63)\end{array}$} & \multicolumn{2}{c}{$\begin{array}{c}\text { Senior(S) } \\
(\mathrm{n}=64)\end{array}$} & $\mathrm{p}$ \\
\cline { 2 - 6 } & $\overline{\mathrm{x}}$ & $\mathrm{SD}$ & $\overline{\mathrm{x}}$ & $\mathrm{SD}$ & $\mathrm{J}-\mathrm{S}$ \\
\hline Neuroticism (pts) & 18.84 & 4.48 & 15.17 & 3.75 & $* * *$ \\
Extroversion (pts) & 30.84 & 4.80 & 30.83 & 4.87 & $\mathrm{NS}$ \\
Openness (pts) & 23.97 & 4.65 & 23.72 & 4.64 & $\mathrm{NS}$ \\
Agreeableness (pts) & 27.89 & 4.48 & 26.89 & 4.81 & $\mathrm{NS}$ \\
Diligence (pts) & 30.75 & 4.52 & 31.28 & 6.06 & $\mathrm{NS}$ \\
\hline
\end{tabular}

$* \mathrm{p}<0.05,{ }^{* *} \mathrm{p}<0.01,{ }^{* * *} \mathrm{p}<0.001, \mathrm{NS}-$ statistically insignificant $(\mathrm{p}>0.05)$

The study of psychological variables of taekwondo competitors in the junior category revealed only one layer of personality - extroversion, which significantly differentiated the groups of subjects (medallist, non-medallist). Competitors winning medals recorded a $9 \%$ higher value extroversion in comparison to competitors who did not win medals (Table 3 ).

Table 3. Psychological traits of the tested competitors winning and not winning medals in the junior category

\begin{tabular}{|c|c|c|c|c|c|c|c|}
\hline \multirow[b]{2}{*}{ Trait } & \multicolumn{3}{|c|}{$\begin{array}{l}\text { Subjects with medals } \\
(\mathrm{n}=27)\end{array}$} & \multicolumn{3}{|c|}{$\begin{array}{l}\text { Subjects without medals } \\
\qquad(\mathrm{n}=36)\end{array}$} & \multirow[t]{2}{*}{$\mathrm{p}$} \\
\hline & $\bar{x}$ & SD & CV \% & $\bar{x}$ & SD & CV \% & \\
\hline Anxiety as state (pts) & 33.7 & 5.2 & 15.4 & 32.0 & 6.2 & 19.4 & 0.252 \\
\hline Anxiety as trait (pts) & 36.3 & 4.9 & 13.5 & 37.3 & 6.6 & 17.7 & 0.520 \\
\hline Briskness (pts) & 15.4 & 2.3 & 14.9 & 14.7 & 2.6 & 17.7 & 0.246 \\
\hline Perseveration (pts) & 11.9 & 2.3 & 19.3 & 12.5 & 2.3 & 18.4 & 0.251 \\
\hline Sensory sensitivity (pts) & 13.0 & 2.8 & 21.5 & 12.6 & 2.8 & 22.2 & 0.614 \\
\hline Emotional reactivity (pts) & 8.7 & 3.4 & 39.1 & 8.6 & 2.5 & 29.1 & 0.843 \\
\hline Endurance (pts) & 12.9 & 3.2 & 24.8 & 13.7 & 3.7 & 27.0 & 0.410 \\
\hline Activity (pts) & 14.4 & 2.5 & 17.4 & 13.9 & 2.9 & 20.9 & 0.446 \\
\hline Neuroticism (pts) & 17.7 & 4.9 & 27.7 & 19.9 & 4.0 & 20.1 & 0.081 \\
\hline Extroversion (pts) & 32.4 & 4.7 & 14.5 & 29.7 & 4.6 & 15.5 & 0.027 \\
\hline Openness (pts) & 23.4 & 4.2 & 17.9 & 24.4 & 5.0 & 20.5 & 0.381 \\
\hline Agreeableness (pts) & 27.6 & 4.4 & 15.9 & 28.1 & 4.6 & 16.4 & 0.613 \\
\hline Conscientiousness (pts) & 31.6 & 4.7 & 14.9 & 30.1 & 4.4 & 14.6 & 0.221 \\
\hline
\end{tabular}

In the group of seniors, agreeableness was the dimension of personality which significantly differentiated competitors with or without medals $(\mathrm{p}<0.05)$. The medallists noted a $19 \%$ higher value of this dimension compared to the remaining competitors without a medal (Table 4).

In the junior category, extroversion was the dimension which differentiated competitors with and without medals. At the same time, agreeableness turned out to be the dimension differentiating competitors with and without medals in the senior category (Fig. 1). 
Baltic Journal of Health and Physical Activity 2020; 12 (2): 35-44

Journal of Gdansk University of Physical Education and Sport

e-ISSN 2080-9999

Table 4. Psychological traits of the tested competitors winning and not winning medals in the senior category

\begin{tabular}{|c|c|c|c|c|c|c|c|}
\hline \multirow[b]{2}{*}{ Trait } & \multicolumn{3}{|c|}{$\begin{array}{l}\text { Subjects with medals } \\
(\mathrm{n}=38)\end{array}$} & \multicolumn{3}{|c|}{$\begin{array}{l}\text { Subjects without medals } \\
\qquad(\mathrm{n}=36)\end{array}$} & \multirow[t]{2}{*}{$p$} \\
\hline & $\bar{x}$ & SD & CV \% & $\bar{x}$ & SD & CV \% & \\
\hline Anxiety as state (pts) & 31.7 & 6.4 & 20.2 & 30.1 & 5.3 & 17.6 & 0.269 \\
\hline Anxiety as trait (pts) & 33.1 & 5.5 & 16.6 & 33.8 & 5.2 & 15.4 & 0.626 \\
\hline Briskness (pts) & 15.1 & 2.9 & 19.2 & 15.6 & 3.1 & 19.9 & 0.561 \\
\hline Perseveration (pts) & 10.6 & 2.1 & 19.8 & 11.7 & 3.0 & 25.6 & 0.104 \\
\hline Sensory sensitivity (pts) & 13.8 & 2.6 & 18.8 & 15.0 & 3.0 & 20.0 & 0.101 \\
\hline Emotional reactivity (pts) & 9.4 & 2.5 & 26.6 & 9.7 & 2.0 & 20.6 & 0.522 \\
\hline Endurance (pts) & 11.1 & 2.6 & 23.4 & 12.0 & 3.4 & 28.3 & 0.219 \\
\hline Activity (pts) & 13.4 & 2.6 & 19.4 & 13.7 & 3.2 & 23.4 & 0.658 \\
\hline Neuroticism (pts) & 15.2 & 3.7 & 24.3 & 15.1 & 3.8 & 25.2 & 0.937 \\
\hline Extroversion (pts) & 30.8 & 3.9 & 12.7 & 30.9 & 5.6 & 18.1 & 0.911 \\
\hline Openness (pts) & 23.4 & 5.3 & 22.6 & 23.9 & 4.2 & 17.6 & 0.663 \\
\hline Agreeableness (pts) & 28.4 & 4.5 & 15.8 & 23.9 & 4.8 & 20.1 & 0.030 \\
\hline Conscientiousness (pts) & 31.3 & 6.4 & 20.4 & 31.3 & 5.9 & 18.8 & 0.963 \\
\hline
\end{tabular}

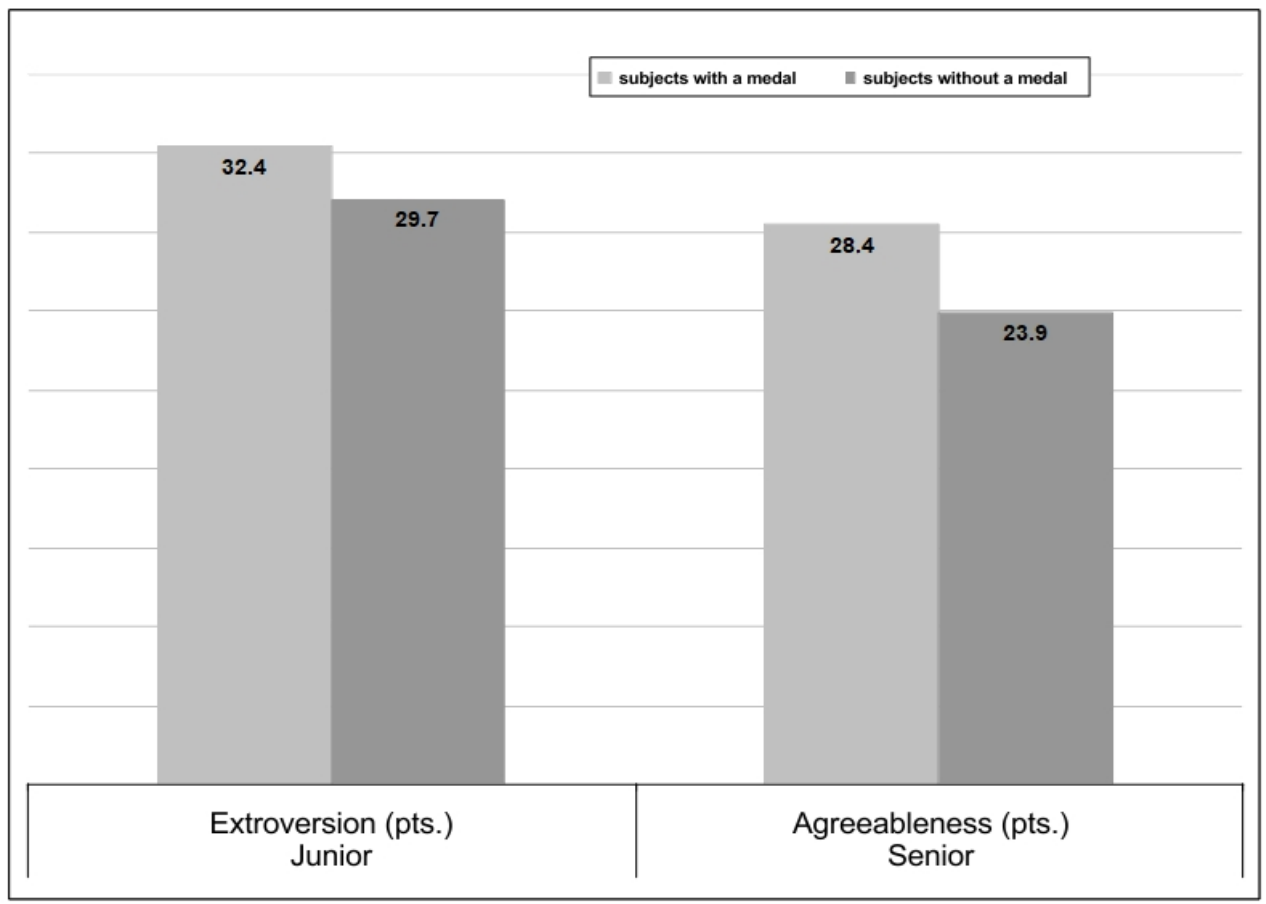

Fig.1. Mental traits differing teams of taekwondo competitors

\section{DISCUSSION}

The aim of the study was to assess and identify psychological factors corresponding with sports performance in Olympic taekwondo of mixed-ability group of competitors. The competitors that were most often tested were highly qualified competitors in the senior group. The attempts to test juniors were sporadic and measured individual factors, i.e. structural, motor, energetic or technical ones. As far as we know, so far there have been no studies undertaking the psychological variables determining sports performance in the junior and senior groups by means of the same methods, techniques and instruments. 
That is why the attempt to identify these factors was undertaken among mixedability competitors using the same methods in each of the presented groups.

Overall, in the junior group the only dimension of personality which differentiated significantly medallists from non-medallists was extroversion $(p<0.05)$. Juniors winning medals demonstrated a high degree of the development of this trait, obtaining a $9.1 \%$ higher value than non-medallists. Particularly noteworthy is the fact that medallists in a junior group tested a low level of anxiety (3-5\%), a high level of the development of the personality trait which was conscientiousness (5\%) and a low level of neuroticism, which was lower by $12 \%$ compared to the group of competitors not achieving success in sports $(\mathrm{p}<0.05)$. To sum up the characteristics of psychological factors of the junior group, it must be stated that medallists significantly differed from non-medallists only with regard to the level of extroversion. This variable corresponded with the sport performance in the tested group. The results obtained were presented against the background of the results of studies of juniors from other martial arts, because such studies are scarce among taekwondo competitors.

Similar study results were presented by Bernatek [3]. They distinguished extroversion as a significant trait characterising junior category competitors achieving sport successes in karate. The medallists from this group were characterised by a high level of extroversion.

Highly qualified juniors practising judo displayed a high level of extroversion and a low level of neuroticism [14]. Rychta [8] also pinpointed a low level of neuroticism in juniors from a judo team who were winning medals. The above data lead to a conclusion that low neuroticism may be an important factor determining the achievement of high sports performance in the abovementioned martial arts.

On the other hand, Obminski et al. [13] conducted a study measuring anxiety, temperament and personality in boxing competitors - juniors winning and not winning medals, and did not find any major differences. The discrepancy of the study results may be determined by the peculiarity of each of the martial arts (judo, boxing, karate). A scarcity of studies on the subject does not provide enough ground for formulating conclusions in the matter.

In the senior group the trait that significantly differentiated the medallists from non-medallists was agreeableness $(\mathrm{p}<0.05)$. The medallists demonstrated a $19 \%$ higher value of this trait than non-medallists. Seniors winning medals had a low level of anxiety, neuroticism, openness and they demonstrated a high level of extroversion; however, these did not differ in the two groups of competitors significantly $(\mathrm{p}<0.05)$.

Similar results were presented by Botwina [9], who showed a high level of extroversion and low level of neuroticism in the top wrestling competitors in the senior group $(p<0.05)$. Thus, we can assume that with the rise of the level of advancement, the factors differentiating competitors with sport success in taekwondo and wrestling are similar. However, it needs to be confirmed with subsequent study.

The results obtained in our research are in line with the results presented by Remiszewska et al. [24] who studied the Polish championship medallists from a senior group in taekwondo. The following psychological factors were included 
as corresponding with the sports performance: a low level of neuroticism and a high level of extroversion $(p<0.05)$.

Summing up, it must be stated that the only mental dimension that significantly differed juniors with and without medals was extroversion. The medallists also had a record of a lower level of anxiety and a higher level of conscientiousness; however, these differences were statistically insignificant $(p<0.05)$.

On the other hand, one personality dimension (agreeableness) was noted to be significantly differentiating the competitors with and without medals $(p<0.05)$. Moreover, the competitors with sports success (with a medal) were characterised by a slightly lower level of anxiety and a high extroversion ( $p>0.05)$.

The research on psychological variables in relation to sport performance in martial arts is scarce. As a result, an attempt for such analysis in relation to other martial arts, i.e. judo, boxing and karate was made in the discussion. The analyses carried out do not fully reflect the specificity of the mental factors differing significantly taekwondo competitors with and without medals, in the junior and senior group. Nevertheless, the comparative analysis of the results of juniors and seniors suggests an observation that the two examined groups showed similarities regarding the low level of anxiety and neuroticism, a high level of extroversion and an average level of agreeableness. Although they were not statistically significant, they indicate a direction for future research.

\section{CONCLUSIONS}

1. As a result of the conducted analysis it was found that the two tested groups (juniors and seniors) showed similarities regarding a low level of anxiety and neuroticism, a high level of extroversion and an average level of agreeableness.

2. Only one variable differed significantly competitors in senior and junior categories, namely neuroticism.

3. In the junior category, the mental factor differing competitors with and without a medal was extroversion, in the senior category - agreeableness.

\section{REFERENCES}

[1] Weinberg R.S. The mental advantage. Champaign: Leisure Press; 1988.

[2] Widyastuti CD. Porównanie umiejętności psychologicznych pomiędzy Pencak Silat i Karate [Comparison of psychological skills between Pencak Silat and Karate]. IDO RUCH DLA KULTURY. Journal of Martial Arts Anthropology. 2019;19(3):50-55. Polish.

[3] Bernatek P, Cwyl S, Dudziak D, Szastarek I, Guszkowska M. Cechy temperamentu i osobowości zawodników sportów walki i zespołowych gier sportowych [Temperament and personality traits of martial arts and team sports players]. In: Parzelski D, editor. Psychologia w sporcie. Teoria, Badania, Praktyka [Psychology in Sport. Theory, Research, Practice]. Warszawa; 2006, 50-57. Polish.

[4] Nia ME, Besharat MA. Comparison of athletes' personality characteristics in individual and team sports. Procedia - Social and Behavioral Sciences. 2010;5:808-812. https://doi.org/10.1016/j. sbspro.2010.07.189

[5] Allen MS, Greenlees I, Jones MV. An investigation of the five-factor model of personality and coping behaviour in sport. J Sport Sci. 2011;29(8):841-850. https://doi.org/10.1080/02640414.2011.565064

[6] Wielochowski M, Gorący A, Żyto-Sitkiewicz D. Ocena funkcjonowania startowego zawodników sportów walki [Assessment of the start performance of combat sports players]. Roczniki Naukowe AWF. 1992;XXXIII:163-189. Polish

[7] Graczyk M. Symptomy patologii zachowania jako efekty uprawiania pięściarstwa [Symptoms of pathology of behavior as the effects of boxing]. In: Maroszek K, editor. Zjawiska patologii społecznej w sporcie [Phenomena of social pathology in sport]. Gdańsk; 1994. Polish.

[8] Rychta T. Osobowość a zachowanie celowe sportowców [Personality and purposeful behavior of athletes]. Warszawa: COS; 1998. Polish 
[9] Botwina R. Osobowościowo-temperamentalne uwarunkowania sukcesu w zapasach juniorów i seniorów [Personality and temperament conditioning of success in junior and senior wrestling]. In: Mikołajczyk M, editor. Korelaty psychologiczne aktywności ruchowej i sukcesów w sporcie. Z badań nad osobowością sportowców i studentów uczelni wychowania fizycznego [Psychological correlates of physical activity and sport successes. From research on the personality of athletes and students of physical education colleges]. Warszawa: PTNKF; 2004, 41-47. Polish.

[10] Piepiora P, Petecka A. Profil osobowości kobiet uprawiających sporty kontaktowe na przykładzie zawodników karate Kyokushin i piłkarzy ręcznych [Personality profile of women practicing contact sports on the example of Kyokushin karate players and handball players]. RUCH KULTURY IDO. Journal of Martial Arts Anthropology. 2020;20(1):23-29.

[11] Sadowski J, Miller JF. Czynniki Warunkujące wynik sportowy w taekwondo olimpijskim [Factors conditioning the sports score in the Olympic taekwondo]. Biała Podlaska: WWFiS; 2016. Polish.

[12] Cynarski WJ, Sieber L. Trening wschodnich sztuk walki - koncepcja holistyczna [Training of eastern martial arts - holistic concept]. Sport Wyczynowy. 2006;11-12:5-15. Polish.

[13] Obmiński Z, Mroczkowska H, Kownacka H, Stabno J. Personality traits and eye-hand co-ordination in less-and more successful young male boxers. J Combat Sport Mart Arts. 2011;2:83-89. https:// doi.org/10.5604/20815735.1047139

[14] Terelak JF, Górska Z. Zależność pomiędzy cechami osobowości wg H.J. Eysencka, a osiągnięciami sportowymi zawodników judo [Relationship between personality traits according to H.J. Eysencka, and the sporting achievements of judo players.] Kultura Fizyczna. 2010;8:1-9. Polish.

[15] Rychta T. Zachowanie celowe a osobowość sportowca [Deliberate behavior and the personality of the athlete]. In: Rychta T, editor. Zachowanie celowe w sporcie a osobowość. Sekcja Psychologii Sportu [Deliberate behavior in sport and personality]. Warszawa: Sport Psychology Section, PTNKF; 1998. Polish.

[16] Ghorbanzadeh B, Muniroglu C, Akalan M, Khodadadi R, Kirazci S, Sahin M. Determination of Taekwondo National Team Selection Criterions by Measuring Physical and Physiological Parameters. Scholars Research Library. Annals of Biological Research. 2001;2(6):184-197.

[17] Kazemi M, Waalen J, Morgan Ch, White AR. Combat sports Special Issue research article. A profile of olympic taekwondo competitors. J Sport Sci Med CSSI. 2006:114-121.

[18] Saporta J. Juan Moreno's Olympic-style training for taekwondo competitors. Journal of Asian Martial Arts. 2006;3(15):39-53.

[19] Wrześniewski K, Sosnowski T, Jaworowska A, Fecenec D. Inwentarz stanu i cech lęku STAI. Polska adaptacja STAI. Podręcznik. Pracownia testów psychologicznych [Inventory of state and features of STAI anxiety. Polish adaptation of STAI. Coursebook]. Warszawa: Pracownia Testów Psychologicznych; 2006. Polish.

[20] Zawadzki B, Strelau J. Formalna charakterystyka zachowania - Kwestionariusz temperamentu (FCZ-KT). Podręcznik [Formal characteristics of behavior - Temperament Questionnaire (FCZ-KT). Coursebook]. Warszawa: Psychological tests workshop; 1997. Polish.

[21] Zawadzki B, Strelau J, Szczepaniak P, Śliwińska M. Inwentarz Osobowości NEO -FFI Costy i McCrae. Adaptacja polska. Podręcznik [Personality Inventory NEO -FFI Costa and McCrae. Polish adaptation. Coursebook]. Warszawa: Pracownia Testów Psychologicznych;1998. Polish.

[22] Stupnicki R. Biometria. Krótki zarys [Biometrics. A brief outline]. Warszawa: Margos; 2000. Polish.

[23] Stanisz A. Przystępny kurs statystyki z zastosowaniem STATISTICA PL na przykładach z medycyny. T.1. Statystyki podstawowe. T.2. Modele liniowe i nieliniowe. T.3. Analizy wielowymiarowe [Affordable statistics course using STATISTICA PL on examples from medicine. T.1. Basic statistics. T.2. Linear models and nonlinear. T.3. Multidimensional analyses.]. Kraków: StatSoft; 2007. Polish.

[24] Remiszewska M, Surawska M, Miller JF. Związki pomiędzy osobowością a sukcesem sportowym $\mathrm{w}$ taekwondo olimpijskim [Relationships between personality and sport success in the Olympic taekwondo]. Scientific Yearbooks; 2018;3(25):25-32. Polish. 